\title{
PRODUCTION OF TNF- $\alpha$ BY PRIMARY CULTURES OF HUMAN KERATINOCYTES CHALLENGED WITH Loxosceles gaucho VENOM
}

\author{
Ceila M. S. MÁLAQUE(1), Maria ORI(2), Sânia A. SANTOS(1) \& Dahir R. ANDRADE(1)
}

\begin{abstract}
SUMMARY
Primary cultures of human keratinocytes were challenged with increasing doses from $10 \mathrm{ng} / \mathrm{mL}$ to $2 \mu \mathrm{g} / \mathrm{mL}$ of Loxosceles gaucho venom, responsible for dermonecrotic lesion in humans. TNF- $\alpha$ was investigated by bioassay and ELISA in the supernatant of the cultures challenged with $100 \mathrm{ng} / \mathrm{mL}, 500 \mathrm{ng} / \mathrm{mL}, 1$ and $2 \mu \mathrm{g} / \mathrm{mL}$ of venom. TNF- $\alpha$ was detected by bioassay in the supernatant of cultures challenged with $100 \mathrm{ng} / \mathrm{mL}$, after $6 \mathrm{~h}$. The cytokine was detected by ELISA in the supernatant of the cells challenged with doses of $1 \mu \mathrm{g} / \mathrm{mL}$, after 6 and $12 \mathrm{~h}$. The results point out the capacity of this venom to activate the keratinocytes in primary cultures to produce TNF- $\alpha$. The production of cytokines could contribute to the local inflammatory process in patients bitten by Loxosceles $s p$.
\end{abstract}

KEYWORDS: Loxosceles; Keratinocytes; Cell culture; TNF- $\alpha$

\section{INTRODUCTION}

Loxosceles spider causes both a cutaneous necrosis and, less frequently, a cutaneous-visceral form of envenomation in humans where, besides the local lesion, hemolysis is also present. The bite is relatively painless and only 2-8 $\mathrm{h}$ after bite patients complain of pain. There may be transient erythema, swelling and mild to severe tenderness. The erithema turns to a violaceous color. An scar may form, between 3 and 7 days, and drop off, leaving an ulcer that heals in varying lengths of time (6-8 weeks), but sometimes also require skin grafting?

Histopathologic changes include edema and thickening of endothelium of blood vessels, collections of inflammatory cells, vasodilation, intravascular coagulation, hemorrhage into the dermis and even into the subcutis. The accumulation of polymorphonuclear leucocytes (PMNs) is especially marked ${ }^{27,28}$.

Several purified components of Loxosceles venom have been identified. The most important component is sphingomyelinase D, a 32-35 $\mathrm{kDa}$ fraction that may produce necrotic lesions, hemolysis of red blood cells and death of experimental laboratory animals $\mathrm{s}^{2,3,4,18,23}$. The kind of sphingomyelinase (SMase) of Loxosceles venom that possesses an optimal activity at $\mathrm{pH} 7.1^{8}$, allows us to characterize it as a neutral sphingomyelinase. This sphingomyelinase hydrolyses the sphingomyelin of the cellular membrane, originating the sphingolipid ceramide $^{12,13}$.
PATEL et al. ${ }^{26}$ demonstrated that $L$ recluse venom activates endothelial cells that express selectin E (CD62a) and causes liberation of IL-8 and GM-CSF. MODUR et al. ${ }^{22}$, studying endothelial cells in primary culture, observed that both the synthetic ceramide (C8-ceramide) and that produced by the action of exogenous sphingomyelinase (sphingomyelinase C) activate synthesis of adhesion molecules by endothelial human cells, delimiting the inflammatory process. Ceramide, in a similar way to the sphingomyelinase D of Loxosceles venom, induces the endothelial cells to link to the activated neutrophils, through the selectin E and of IL-8. This phenomenon helps explain the exuberant presence of neutrophils in the dermonecrotic lesions of Loxosceles envenomation.

An important aspect of the phenomenon originates in the epidermis because it is where the venom takes place primarily, in the transition of the layer epiderm-derm. In this context, it is justifiable to choose the keratinocyte as one of the target cells, based on evidences of NICKOLOFF \& TURKA ${ }^{25}$, that have established the mechanisms of exogenous aggression of the skin by physical agents as ultraviolet, contact allergens, microorganisms, etc. Activated keratinocytes convert exogenous stimuli, by appropriate transcription factors, in coding cytokines genes, adhesion molecules and chemotatic factors responsible for the initiation of the cutaneous inflammation ${ }^{1,5,17,21,25}$.

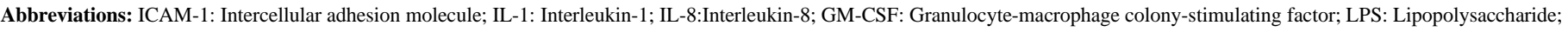
MHC II: Major histocompatibility complex II; UV: Ultraviolet; VCAM-1: vascular cell adhesion molecule 1.This work was supported by CNPq and CAPES.

(1) Laboratório de Investigação Médica (LIM 54), Hospital das Clínicas da Faculdade de Medicina da Universidade de São Paulo (HCFMUSP), São Paulo, SP, Brasil.

(2) LIM 12, HCFMUSP, São Paulo, SP, Brasil.

Correspondence to: Ceila Maria Sant'Ana Málaque, Hospital Vital Brazil, Instituto Butantan. Av. Vital Brazil 1500, 05503-900 São Paulo, SP, Brazil. Phone: (011) 3061-9809. e-mail: naputano@uol.com.br
} 
The objective of this study was to describe the keratinocytes cultures and to assess the presence of TNF- $\alpha$ in the supernatant of human keratinocytes cultures challenged with Loxosceles gaucho venom.

\section{MATERIAL AND METHODS}

Venom: Venom collected from the fangs of Loxosceles gaucho by electrical stimulation of the spider was provided by Section of Venom of Instituto Butantan, obtained by electrostimulation by the method of BÜRCHEL ${ }^{7}$, with slight modifications, lyophilized and stored at $-20^{\circ} \mathrm{C}$. It was diluted in saline, aliquoted and stored at $-20{ }^{\circ} \mathrm{C}$.

Cell Culture: Foreskins obtained from routine circumcisions were washed in $70 \%$ alcohol for 20-30 s and transferred to a medium containing high concentration of antibiotics, for $15 \mathrm{~min}^{31}$. After separating derma/epidermis mechanically, the tissue was cut into pieces of $1 \times 1$ $\mathrm{mm}$ and placed into $25 \mathrm{~cm}^{2}$ plastic flasks (Nunc). After $22 \mathrm{~h}$ at $37{ }^{\circ} \mathrm{C}$ and in $5 \% \mathrm{CO}^{2}, 4 \mathrm{~mL}$ of the culture medium (K-SFM; Gibco) was carefully added to ensure that all pieces were covered by culture medium. The flasks were then incubated at $37{ }^{\circ} \mathrm{C}$ and with $5 \% \mathrm{CO}_{2}$. After 5 days, the flasks were inspected to observe epidermal cell growth. The culture medium was replaced 2 to 3 times per week up to the confluence of the cells.

Loxosceles gaucho venom diluted in RPMI-1640 (Sigma) and concentrations of $10 \mathrm{ng} / \mathrm{mL}, 100 \mathrm{ng} / \mathrm{mL}, 200 \mathrm{ng} / \mathrm{mL}, 500 \mathrm{ng} / \mathrm{mL}, 1 \mu \mathrm{g} / \mathrm{mL}$ e $2 \mu \mathrm{g} / \mathrm{mL}$ were added to monolayer cultures of keratinocytes which were inspected 6,12, 24 and $36 \mathrm{~h}$ after challenge to assess the venom effects.

Electron microscopy: Cultures of keratinocytes exposed to $2 \mu \mathrm{g} / \mathrm{mL}$ of $L$. gaucho venom were detached by trypsin solution (trypsin $0.2 \%$; EDTA in PBS $0.02 \%$ - Instituto Adolfo Lutz). The supernatant was centrifuged and glutaraldehyde was added to the pellet for $2 \mathrm{~h}$. It was post-fixed in osmium $1 \%$, block stained in $0.5 \%$ uranyl acetato, overnight, and dehydrated in a graded series of ethanol, acetone and araldite resin. The preparation was examined by electron microscopy (JEOL).

Microbiologic analysis of the contaminated cultures: Of those culture media that became turbid, $100 \mu \mathrm{L}$ were removed, placed in tube contends TSB (Tryptic Soy Broth, DIFCO), and maintained by $24 \mathrm{~h}$ for $37^{\circ} \mathrm{C}$. Later, a plate of agar-blood was sowed (middle of Müeller-Hinton, DIFCO, with 5\% defibrinated ovine red blood cells, Biotério Boa Vista) with darkened TSB. Identification of the microorganism was carried out by analysis of the morphologic characteristics of the colonies and Gram staining.

Bioassay for TNF- $\alpha$ : Confluent keratinocytes cells were treated with venom concentrations of $100 \mathrm{ng} / \mathrm{mL}, 500 \mathrm{ng} / \mathrm{mL}, 1 \mu \mathrm{g} / \mathrm{mL}$ and 2 $\mathrm{mg} / \mathrm{mL}$ in RPMI-1640. After different incubation periods $(0,6,12,24$, $36 \mathrm{~h}$ ), an aliquot of cell culture supernatant was removed and TNF- $\alpha$ was investigated by bioassay. Briefly, L929 cells were seeded at the concentration of $3 \times 10^{4}$ cells/well of a 96-well, in $100 \mu \mathrm{L}$ culture medium RPMI-1640 (Sigma), and incubated at $37{ }^{\circ} \mathrm{C}$ and at $5 \% \mathrm{CO}_{2}$ atmosphere to establish a dense monolayer. Actinomycin $\mathrm{D}$ was added at the concentration of $1 \mu \mathrm{g} / \mathrm{mL}$ and incubated for $2 \mathrm{~h}$. Samples were tested in duplicate or triplicate. After $24 \mathrm{~h}$ incubation at $37{ }^{\circ} \mathrm{C}$, in $5 \%$ $\mathrm{CO}_{2}$, the plates were rinsed and stained with MTT (3-(4,5-dimethylthia- zol-2-yl)-2,5-diphenyl tetrazolium bromide), $500 \mu \mathrm{g} / \mathrm{mL}$. The optical density (O. D.) was measured, after $1 \mathrm{~h}$, at $595 \mathrm{~nm}$ on BIO-RAD microplate reader. Percentage viability was calculated using the formula:

$$
\frac{\text { O.D. (test) }}{\text { O.D. (control) }} \times 100 \text {, }
$$

where control cells were incubated with culture medium only. Results were compared with a standard curve of human recombinant TNF- $\alpha$ and expressed as $\mathrm{pg} / \mathrm{mL}$.

ELISA: Confluent keratinocytes were exposed to venom at $500 \mathrm{ng} / \mathrm{mL}, 1 \mu \mathrm{g} / \mathrm{mL}$ and $2 \mu \mathrm{g} / \mathrm{mL}$ in RPMI-1640. After different incubation periods $(0,6,12,24,36 \mathrm{~h})$, an aliquot of cell culture medium was removed. Human TNF- $\alpha$ (hTNF- $\alpha$ ) was investigated in the supernatant by a commercially available ELISA kit (Boehringer Mannheim). Detection of standard TNF- $\alpha$ was linear over the range $20-800 \mathrm{pg} / \mathrm{mL}$. The limit of detection was $\geq 12 \mathrm{pg} / \mathrm{mL}$ and limit of quantification was $\geq 20 \mathrm{pg} / \mathrm{mL}$.

\section{RESULTS}

\section{Cell culture}

Initially contamination was frequent and could be observed from the 4th day of culture, when the culture medium become turbid. The isolated microorganisms were Candida spp. and Streptococcus spp. We observed that the tissues of children $\geq 2$ and $<3$ year old children had a higher contamination rate (56.2\%) when compared to other groups.

The beginning of the cellular growth occurred from the 7th to the 10th day of culture. Cells had a polygonal format, with large nucleus, prominent nucleoli and cytoplasm with variable number of granules. By electron microscopy, organelle and cytoplasmic filaments were observed in the perinucleus, and intercellular contacts by microvilli.

Development of monolayer, necessary to allow the addition of the venom, occurred about the 21 st day. With K-SFM (GIBCO), no contamination was observed with fibroblasts in the primary cultures. However, after two passages of some cultures, there was an exuberant growth of fibroblasts not allowing the continuation of the subcultures.

\section{Effects of Loxosceles gaucho venom on the keratinocytes cultures}

There were no changes in cell morphology assessed by optical microscopy after 36 hour-contact with the venom at concentrations of 10 to $500 \mathrm{ng} / \mathrm{mL}$. Even challenging the cells with $10 \mathrm{ng} / \mathrm{mL}$ to $200 \mathrm{ng} / \mathrm{mL}$ of venom, cells continued to be cultured for 4 weeks, denoting its viability. On the other side, cells incubated with venom at $500 \mathrm{ng} / \mathrm{mL}$ died after 5 days. When using 1 and $2 \mu \mathrm{g} / \mathrm{mL}$, after $36 \mathrm{~h}$ of contact with venom, the cells showed increase of granulation and cytoplasm vacuolation, cellular death and detached cells when compared to the control. Cells challenged with $2 \mu \mathrm{g} / \mathrm{mL}$, observed by electron microscopy after $36 \mathrm{~h}$ of incubation, showed vacuoles increase in the cytoplasm.

\section{Detection of TNF- $\alpha$ by bioassay and ELISA}

By bioassay, $7.0 \mathrm{pg} / \mathrm{mL}$ of TNF- $\alpha$ was detected in the supernatants of keratinocyte cultures challenged with $100 \mathrm{ng} / \mathrm{mL}$ of the toxin for $6 \mathrm{~h}$. With the other concentrations, we did not detect the presence of TNF- $\alpha$. 
By ELISA, TNF- $\alpha$ was detected, 6 and $12 \mathrm{~h}$ after challenge with 1 $\mu \mathrm{g} / \mathrm{mL}$ of venom (Fig. 1). With $2 \mu \mathrm{g} / \mathrm{mL}$, the levels were below of the limit of quantification of the test $(\mathrm{T} 36=18 \mathrm{pg} / \mathrm{mL})$ (Fig. 2); with 500 $\mathrm{ng} / \mathrm{mL}$, no TNF- $\alpha$ was detected.

\section{DISCUSSION}

The choice of human keratinocytes as target cells to the action of $L$. gaucho toxin is based on two different aspects. One is the hypothesis that the deposition of the venom occurs in the transition between epidermis and derma. The other is the fact that keratinocytes have, beside their coating function, important immunological functions, reacting to external insult with cytokine production (TNF-to, IL-1, IL-8), expression of adhesion molecules (ICAM-1, VCAM-1) and of molecules of the MHC II ${ }^{5,24,25}$. Cellular culture could facilitate the study of the interaction of toxin and cells, thus allowing to evaluate its behavior when challenged by toxins.

Some considerations could be made about the primary cultures of keratinocytes. Contamination was a limiting factor to the development of the culture. The source of contamination was the tissue obtained from foreskin of children submitted to circumcision. The isolated microorganisms were Streptococcus sp. and Candida sp, present in the flora of

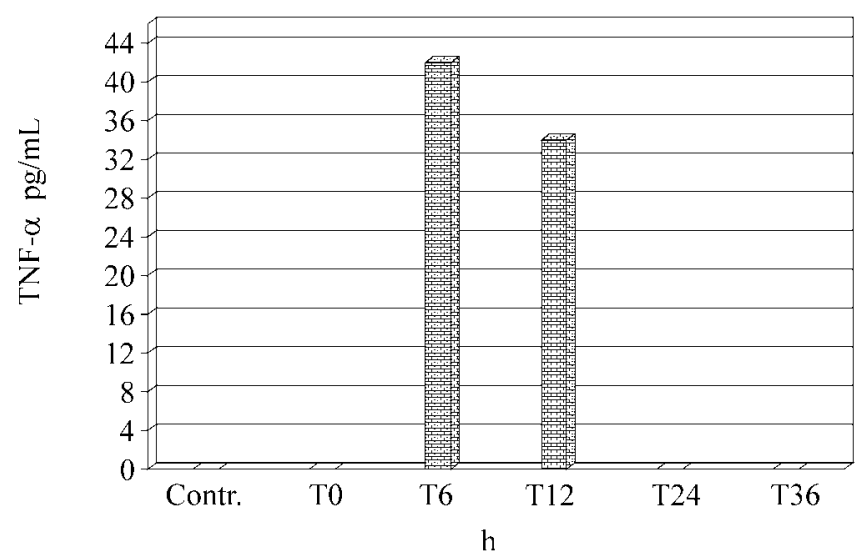

Fig. 1 - TNF- $\alpha$ by ELISA in supernatant of keratinocytes challenged with L. gaucho venom $-1 \mu \mathrm{g} / \mathrm{mL}$.

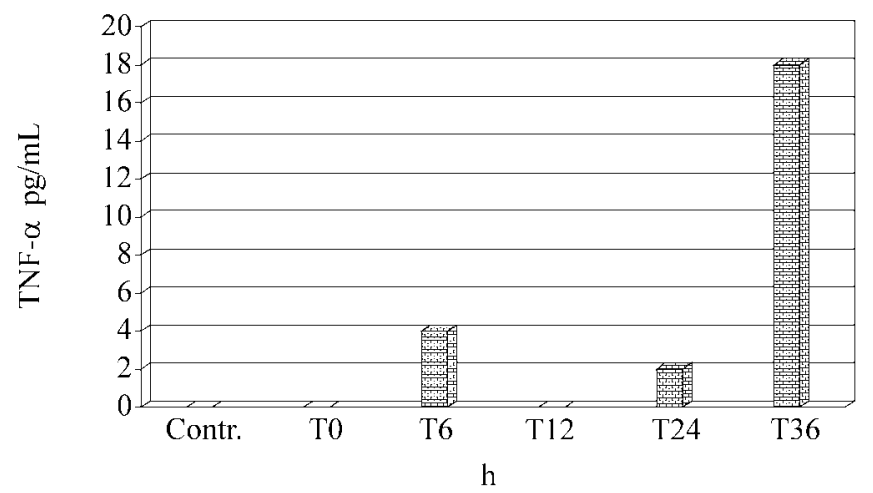

Fig. 2 - TNF- $\alpha$ by ELISA in supernatant of keratinocytes challenged with L. gaucho venom $-2 \mu \mathrm{g} / \mathrm{mL}$. genital area. The infections were more frequent in the tissues of 2 to 3 year old-children, the age group where that surgery is mostly indicated.

The cellular growth began from the 7 th to the 10th day. In 2 to 3 weeks, the cells were confluent, forming a monolayer as a pavement, with large nucleus and prominent nucleoli, as referred in the literature $^{29,31,32}$. The visualization of the cells by electron microscope revealed cells with perinuclear filaments, similar to those previously described $^{29}$. As observed in cultures of mice keratinocytes ${ }^{14}$, the intercellular contacts are made by microvilli, probably because the culture medium contained low concentrations of calcium $(0.09 \mathrm{mM} \mathrm{Ca}++)$, that inhibited the desmosomes formation.

When the cultures formed a cellular monolayer reaching $60-70 \%$ of the bottle, the cells were challenged with the toxin. Increasing doses of venom were used, from $10 \mathrm{ng} / \mathrm{mL}$ until $2 \mu \mathrm{g} / \mathrm{mL}$ with the purpose of observing the behavior of the cells. With doses of $500 \mathrm{ng} / \mathrm{mL}$ to $2 \mu \mathrm{g} / \mathrm{mL}$, cellular damage and death were observed, occurring earlier with larger doses. The difficulty to obtain a subculture, as referred previously ${ }^{6}$, did not allow us to make tests of cellular viability, time and dose dependent to the challenge with the venom.

The levels of TNF- $\alpha$ detected in the supernatant by ELISA were comparable to those described when the keratinocytes were stimulated with $\mathrm{UV}^{16}$ and $1 \alpha, 25$ dihydroxyvitamin $\mathrm{D} 3^{11}$. With $1 \mu \mathrm{g} / \mathrm{mL}$ of venom, $42 \mathrm{pg} / \mathrm{mL}$ and $34 \mathrm{pg} / \mathrm{mL}$ of TNF- $\alpha$ were detected 6 and $12 \mathrm{~h}$ after challenge, respectively. It is interesting to notice that either by bioassay or ELISA, TNF- $\alpha$ was detected 6 hours after challenge and it is possible that the detection could be made earlier as referred by GEILEN et al. ${ }^{11}$.

The presence of the TNF- $\alpha$, observed in some experiments accomplished with keratinocytes cultures, may contribute to the understanding the role of cytokines to localize the inflammatory process, as mentioned by NICKOLOFF \& TURKA ${ }^{25}$. The eventual presence of ceramide in the endothelial cells, resulted from Loxosceles sphingomyelinase activity $^{26}$, associated to TNF- $\alpha$ production by keratinocytes, could explain the synthesis of adhesion molecules and the intense inflammatory deviation that are observed in the lesions.

The L. gaucho venom activity on the keratinocytes reveals its potentiality as agent of cellular death. GEILEN et al. ${ }^{11}$, using permeable ceramide in cellular lineage of human keratinocytes (HaCaT), observed apoptosis induction, measured by fragmentation of DNA and electron microscopy. The action of the ceramide, resultant of the sphingomyelin's cleavage of by sphingomyelinase, may lead to death by apoptosis (a pathway involving caspases) or necrosis. The TNF- $\alpha$, a powerful cytotoxic agent, is also responsible for cellular death, using as intracellular second messenger the ceramide, that leads cytocrome c production and activation of caspases ${ }^{15,19,20,30}$. Therefore, it is possible that, in the lesion caused by Loxosceles spider, signs triggered by ceramide and action of TNF- $\alpha$ result in cellular death by necrosis and/or apoptosis ${ }^{10,19,21}$.

\section{RESUMO}

Produção de TNF- $\alpha$ por queratinócitos humanos em cultura primária após agressão com veneno de Loxosceles gaucho 
Culturas primárias de queratinócitos humanos foram incubadas com veneno de aranha Loxosceles gaucho, que possui atividade esfingomielinase $\mathrm{D}$, responsável por lesão dermo-necrótica nos acidentes humanos. As células das culturas primárias foram agredidas com o veneno em doses crescentes de $10 \mathrm{ng} / \mathrm{mL}$ a $2 \mu \mathrm{g} / \mathrm{mL}$. No sobrenadante das culturas agredidas com $100 \mathrm{ng} / \mathrm{mL}, 500 \mathrm{ng} / \mathrm{mL}, 1$ e $2 \mu \mathrm{g} / \mathrm{mL}$ da toxina, foi pesquisada a presença de TNF- $\alpha$ através de bioensaio e ELISA. Com $100 \mathrm{ng} / \mathrm{mL}$, foi detectado TNF- $\alpha$ no sobrenadante após $6 \mathrm{~h}$, no bioensaio; usando o teste de ELISA, detectou-se a citocina no sobrenadante de células agredidas com doses de $1 \mu \mathrm{g} / \mathrm{mL}$, após 6 e $12 \mathrm{~h}$. Os resultados apontam para a capacidade deste veneno em ativar os queratinócitos em cultura, levando-os a produzir TNF- $\alpha$. É provável que a produção de citocinas ative as células endoteliais, auxiliando na localização do processo inflamatório.

\section{ACKNOWLEDGMENT}

We are greatly indebted to Fan Hui Wen for her help.

\section{REFERENCES}

1. ANSEL, J.; PERRY, P.; BROWN, J. et al. - Cytokine modulation of keratinocyte cytokines. J. invest. Derm., 94: 101S-107S, 1990.

2. BARBARO, K.C. - Caracterização biológica, imunoquímica e bioquímica do veneno de aranhas do gênero Loxosceles. São Paulo, 1996. (Tese de Doutoramento Instituto de Ciências Biomédicas da Universidade de São Paulo).

3. BARBARO, K.C.; CARDOSO, J.L.C.; EICKSTEDT, V.R.D. \& MOTA, I. - Dermonecrotic and lethal components of Loxosceles gaucho spider venom. Toxicon, 30: $331-338,1992$

4. BARBARO, K.C.; FERREIRA, M.L.; CARDOSO, D.F.; EICKSTEDT, V.R.D. \& MOTA, I. - Identification and neutralization of biological activities in the venoms of Loxosceles spiders. Braz. J. med. biol. Res., 29: 1491-1497, 1996.

5. BARKER, J.N.W.N.; MITRA, R.S.; GRIFFITHS, C.E.M.; DIXIT, V.M. \& NICKOLOFF, B.J. - Keratinocytes as initiators of inflammation. Lancet, 337: 211-214, 1991.

6. BREIDAHL, A.F.; JUDSON, R.T. \& CLUNIE, G.J.A. - Review of keratinocytes culture techniques: problems of growing skin. Aust. N. Z. J. Surg., 59: 485-497, 1989.

7. BÜRCHEL, W. - Biology and venoms of the most important South American spiders of the genera Phoneutria, Loxosceles, Lycosa and Latrodectus. Amer. Zool., 9: 157$159,1969$.

8. FORRESTER, L.J.; BARRET, J.T. \& CAMPBELL, B.J. - Red blood cell lysis induced by the venom of the brown recluse spider. The role of sphingomyelinase D. Arch. Biochem., 187: 355-365, 1978.

9. FUTRELL, J. M. - Loxoscelism. Amer. J. med. Sci., 304: 261-267, 1992.

10. GAMARD, C.J.; DBAIBO, G.S.; LIU, B.; OBEID, L.M. \& HANNUN, Y.A. - Selective involvement of ceramide in cytokine-induced apoptosis. Ceramide inhibits phobol ester activation of nuclear factor kappaB. J. biol. Chem., 272: 16474-16481, 1997.

11. GEILEN, C.C.; BEKTAS, M.; WIEDER, T. et al. - 1 1 2,25 -Dihydroxyvitamin $\mathrm{D}_{3}$ induces sphingomyelin hydrolysis in $\mathrm{HaCaT}$ cells via tumor necrosis factor $\alpha$. J. biol. Chem., 272: 8997-9001, 1997.

12. HANNUN, Y.A. \& BELL, R.M. - Functions of sphingolipids and breakdown products in cellular regulation. Science, 243: 500-507, 1989.

13. HANNUN, Y.A.; OBEID, L.M. \& WOFF, R.A. - The novel second messenger ceramide: identification mechanism of action, and cellular activity. Advanc. Lipid Res., 25: 43-64, 1993.
14. HENNINGS, H.; MICHAEL, D.; CHENG, C. et al. - Calcium regulation of growth and differentiation of mouse epidermal cells in culture. Cell, 19: 245-254, 1980.

15. JARVIS, D.W.; GRANT, S. \& KOLESNICK, R.N. - Ceramide and the induction of apoptosis. Clin. Cancer Res., 2: 1-6, 1996.

16. KÖCK, A.; SCHWARZ, T.; KIRNBAUER, R. et al. - Human keratinocytes are a source for tumor necrosis factor alpha: evidence for synthesis and release upon stimulation with endotoxin or ultraviolet light. J. exp. Med., 172: 1609-1614, 1990.

17. KUPPER, T.S. - The activated keratinocyte: a model for inducible cytokine production by non-bone marrow-derived cells in cutaneous inflammatory and immune responses. J. invest. Derm., 94: 146S-150S, 1990.

18. KURPIEWSKI, G.; FORRESTER, L.J.; BARRET, J.T. \& CAMPBELL, B.J. - Platelet aggregation and sphingomyelinase $\mathrm{D}$ activity of a purified toxin from the venom of Loxosceles reclusa. Biochim. biophys. Acta (Amst.), 678: 467-476, 1981.

19. LEMASTER, J.J. - The mitochondrial permeability transition: from biochemical curiosity to pathophysiological mechanism. Gastroenterology, 115: 783-786, 1998.

20. MATHIAS, S. \& KOLESNICK, R. - Ceramide: a novel second messenger. Advanc. Lipid Res., 25: 65-90, 1993.

21. McKENZIE, R.C. \& SAUDER, D.N. - The role of keratinocyte cytokines in inflammation and immunity. J. invest. Derm., 95: 105S-107S, 1990.

22. MODUR, V.; ZIMMERMAN, G.A.; PRESCOTT, S.M. \& McINTYRE, T. - Endothelial cell inflammatory response to tumor necrosis factor $\alpha$. J. biol. Chem., 271: 1309413102,1996

23. MOTA, I. \& BARBARO, K.C. - Biological and biochemical properties of venoms from medically important Loxosceles (Araneae) species in Brazil. J. Toxicol.-Toxins Rev., 14: 401-421, 1995.

24. NICKOLOFF, B.J. \& NAIDU, Y. - Perturbation of epidermal barrier function correlates with initiation of cytokine cascade in human skin. J. Amer. Acad. Derm., 30: $535-546,1994$.

25. NICKOLOFF, B.J. \& TURKA, L.A. - Keratinocytes: key immunocytes of the integument. Amer. J. Path., 143: 325-331, 1993.

26. PATEL, K.D.; MODUR, V.; ZIMMERMAN, G.A.; PRESCOTT, S.M. \& MCINTYRE, T.M. - The necrotic venom of brown recluse spider induce dysregulated endothelial cell-dependent neutrophil activation. J. clin. Invest., 92: 631-642, 1994.

27. PIZZI, T. - Estudios histopatológicos del aracnidismo necrótico por Loxosceles laeta. Bol. chil. Parasit., 30: 34-36, 1975.

28. REYES, V. \& ATIAS, A. - Un caso clinico de loxoscelismo cutaneo visceral. Bol. Hosp. S. Juan (Santiago), 28: 331-336, 1981.

29. ROSE, B.R.; THOMPSON, C.H.; MCDONALD, A.M. et al. - Cell biology of cultured anogenital warts. Brit. J. Derm., 116: 311-322, 1987.

30. SMYTH, M.; OBEID, L.M. \& HANNUN, Y.A. - Ceramide: a novel lipid mediator of apoptosis. Advanc. Pharmacol., 41: 133-154, 1997.

31. THOMPSON, C.H.; ROSE, B.R. \& COSSART, Y.E. - Optimised growth of human epidermal cells in vitro without the use of a feeder layer or collagen substrate. Aust. J. exp. Biol. med. Sci., 63: 147-156, 1985.

32. VIEIRA, K.B.L. - Cultura de células epiteliais normais ou transfectadas por DNA viral, como um modelo de estudo de Papilomavírus humano. São Paulo, 1991. (Dissertação de Mestrado - Departamento de Bioquímica e Biologia Celular da Escola Paulista de Medicina).

Received: 08 April 1998 Accepted: 16 April 1999 